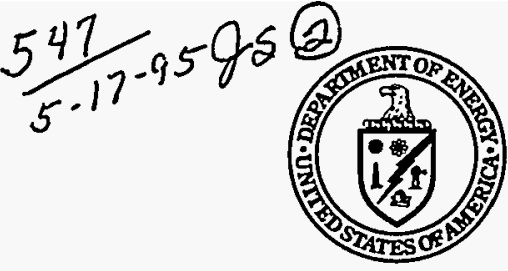

\title{
Environmental Guidance Regulatory Bulletin
}

Office of Environmental Policy \& Assistance $\bullet$ RCRA/CERCLA Division ROE/EH--95011450

April 1995

\section{Alternate Threshold for Facilities with Low Annual Reportable Amounts}

\section{Alternate \\ Threshold; TRI Reporting Final Rule}

\section{Introduction}

Under Section 313 of the Emergency Planning and Community Right-to-Know Act (EPCRA), a facility that meets or exceeds annual reporting thresholds, including the manufacture or process of any listed toxic chemical in quantities equal or greater than 25,000 pounds/year, or otherwise use of any listed toxic chemical in quantities equal or greater than 10,000 pounds/year, must submit a Form R report.

On November 30, 1994, at 59 FR 61488, the U.S. Environmental Protection Agency (EPA) promulgated a final rule that established an alternate reporting threshold of greater than 1 million pounds per year for manufacturing, processing, or otherwise using a listed chemical. If a facility subject to Section 313 reporting does not exceed this threshold, and if a facility's total annual reportable amount (defined below) does not exceed
500 pounds per year, then that facility may submit a certification statement for that chemical instead of the Form R report.

The final rule will be effective for reporting on activities beginning January 1, 1995 pending Office of Management and Budget (OMB) approval. Certification statements will be due each year with Form R reports on or before July 1 for the previous calendar year.

\section{Statutory Authority}

Under Section 313 (f)(2) of EPCRA, EPA has the authority to revise the threshold amounts based on chemical classes or facility categories.

However, such revised threshold amounts must obtain reporting on a substantial majority of total releases of the chemical at all facilities subject to Section 313.

Additionally, Section 6607 of the Pollution Prevention Act, 42 U.S.C. 13106, requires all facilities to report pollution prevention and recycling data for the chemicals listed under EPCRA Section 313.

\section{Background}

The EPA received petitioned requests from the Small Business Administration (SBA) and the American Feed Industry Association (AFIA), on August 8, 1991 and February 14, 1992 respectively, to be exempt from the Toxic Chemical Release Inventory (TRD) reporting requirement due to low volume releases of the listed chemicals. After publishing the AFIA petition in the Federal 
Register on April 13, 1993 and considering the comments that were received, EPA decided to revise the current reporting requirements which could apply to all industries with low annual reportable amounts rather than just a limited number of industries.

EPA issued the alternate threshold rule to relieve small sources of some of the regulatory burden. When establishing the final rule, EPA had to consider:

- facility categories based on the pounds of chemical released and transferred or total of all volumes (i.e., annual reportable amounts) for that chemical;

- alternate reporting threshold levels; and

- certification and degree of burden reduction.

In the July 28, 1994 (59 FR 38524) proposed rulemaking, EPA introduced several options for an alternate threshold for low-level releases and transfers. EPA proposed that a facility whose total annual releases and off-site transfers (for treatment and/or disposal only) are below 100 pounds could be exempted from Form $\mathrm{R}$ reporting. Furthermore, EPA evaluated three other low-level totals (500 pounds, 10 pounds, and 0 pounds). The proposal also considered an alternate threshold based on total waste generation, which includes amounts released on-site, transferred off-site for treatment or disposal, recycled or burned for energy recovery on-site or off-site, and treated on-site.

\section{Final Rule}

For the final rule, EPA decided that a category based on total annual reportable amounts not to exceed 500 pounds will give industry a reasonable and maintainable level while limiting the loss of any pertinent information. EPA defines total annual reportable amounts as the combined totals of the management activities in Sections 8.1 to 8.7 of the Form $\mathrm{R}$ report. These management activities include quantities of the chemical released at the facility, disposed within the facility, treated at the facility, recovered at the facility as a result of recycle operations, combusted for the purpose of energy recovery at the facility, and amounts transferred from the facility to off-site locations for the purpose of recycle, energy recovery, treatment, and/or disposal.

Owners and operators of facilities should be aware that the annual amount of 500 pounds is based on the entire facility and will include all operations within that facility. EPA determined that the alternate threshold of greater than 1 million pounds (representing $99.95 \%$ efficiency) will allow more detailed information to be retained on very large volumes of toxic chemicals.

If a facility does not exceed the 500 pound annual reportable amount total and does not exceed the alternate reporting threshold of 1 million pounds, then the facility may submit an annual certification statement instead of a Form $\mathrm{R}$ report for the listed chemical. The certification statement will be used to indicate and record the presence, release and transfer of a specific chemical at a facility. The data from these certification statements will be entered into the TRI databases and will show that the facility is exercising the alternate threshold.

Most of the information on the certification statement will be similar to the facility identification section of the current Form $\mathrm{R}$ report. It is expected that the cost of completing the certification will be lower. EPA requires facilities 


\section{DISCLAIMER}

This report was prepared as an account of work sponsored by an agency of the United States Government. Neither the United States Government nor any agency thereof, nor any of their employees, make any warranty, express or implied, or assumes any legal liability or responsibility for the accuracy, completeness, or usefulness of any information, apparatus, product, or process disclosed, or represents that its use would not infringe privately owned rights. Reference herein to any specific commercial product, process, or service by trade name, trademark, manufacturer, or otherwise does not necessarily constitute or imply its endorsement, recommendation, or favoring by the United States Government or any agency thereof. The views and opinions of authors expressed herein do not necessarily state or reflect those of the United States Government or any agency thereof. 


\section{DISCLAIMER}

Portions of this document may be illegible in electronic image products. Images are produced from the best available original document. 
to (1) file individual certifications for each distinct chemical that satisfies the alternate threshold requirement and (2) keep accurate records of threshold determinations and estimates of releases and transfers. The certification statements will be retained on an annual schedule to provide adequate data continuity. Failure to submit either the Form $R$ or the certification statement could result in penalties up to $\$ 25,000$ per day per violation.

\section{DOE Comment Resolution}

In comments prepared by the Department of Energy (DOE) on the July 28, 1994 proposed rulemaking, the Department objected to the category of exemption based on total waste generation. DOE argued that since facilities would be required to complete all of the Form $\mathrm{R}$ calculations in order to determine if they are eligible for the alternate threshold, only minimal regulatory burden reduction would be achieved. EPA responded that substantial burden reduction is available by not requiring specific information expected on the full Form $\mathrm{R}$ report such as source reduction activities and waste treatment methods.

DOE also opposed the annual requirement for submission of a certification statement verifying facility exemption since current exemptions to Section 313 reporting do not require a written certification. EPA responded by reiterating that the alternate threshold was not developed to provide a wholesale exemption from Section 313 reporting requirements. EPA believes that the certification statement will provide the public with an adequate level of information and will make this information available through the TRI database.

Finally, DOE requested that the regulatory language of the proposed rule be revised to permit facilities to submit a single certification statement for multiple chemicals instead of one for each listed chemical. However, EPA concluded that current processing techniques would make handling of one form with many chemicals difficult, resulting in submission and handling errors.

\section{DOE Use of Alternate Threshold}

The decision to use the alternate reporting threshold -- if all the criteria are met -- is left to each reporting facility. However, the benefits of submitting a certification instead of a Form $R$ report should be weighed against the fact that most of the chemical tracking and use and release calculations must still be performed in order to certify that the release does not exceed 500 pounds. Equally important, full disclosure by a facility of community right-to-know information (i.e., Form $\mathrm{R}$ report) enhances community relations and supports the Secretary's openness initiative.

\section{For More Information}

For a copy of the Federal Register notice (59 FR 61488, Wednesday, November 30, 1994), call EPA's RCRA/Superfund/EPCRA Hotline in Washington, DC. The national toll-free number is (800) 535-0202 or TDD (800) 553-7672.

Please direct questions regarding this Alternate Threshold final rule to: Jane Powers DOE Office of Environmental Policy \& Assistance RCRA/CERCLA Division 1000 Independence Ave., S.W. Washington, DC 20585 at (202) 586-7301 